\title{
ANALISIS VARIANS MULTIVARIAT TERHADAP RETURN DAN RISIKO PORTOFOLIO YANG DITENTUKAN DENGAN ELTON GRUEBER PADBERG MODEL PADA EMPAT KELOMPOK INDEKS (LQ 45, SRI-KEHATI, JII, DAN ISSI)
}

\author{
Bq. Nurul Suryawati ${ }^{1}$, Laila Wardani ${ }^{2}$, Iwan Kusmayadi ${ }^{3}$, \\ Sulaeman Sarmo ${ }^{4}$
}

\begin{abstract}
This research emphasizes the difference between risk and return on four group of index, which are LQ 45, SRI KEHATI, JII and ISSI. Test of significance conduct by doing Analysis of Varians Multivariate. The Analysis of Varians Multivariate results more accurate than repeatedly t-test among group. EGP Model mostly explained as Single Index Model in various textbook. Thus, Single Index Model only clarified influence of a Single Market Index for Individual Index, EGP Model use Reward to Volatility (RVOL) for measuring excess return to systematic risk.

The results shows that after 15 years from sharia index introduce in Indonesian Stock Exchange, it shows significant difference between sharia index and conventional stock market. However, LQ 45 shows it persistence as high return high risk index consistently. The Analysis VariansMultivariate also shows SRI KEHATI, as an ethic businesses representative in Indonesian Stock Exchange as a weaker index. SRI KEHATI shows that various group portfolio form by EGP Model could not exceed JII performance.

Therefore, it concludes that indexes provide by capital market to facilitise the preference of investor whereas, it is tremendously various. To invest in stock market, investor need to clarify their wants and needs. Whether their wants is to gain more return or to accommodate their risk, and their preferrence to invest in various kind of business or certain business such as business based on ethic or faith.

Keywords: Analysis of Varians Multivariate; Risk and Return; EGP Model; Indexes; LQ 45; Sri-Kehati; Jakarta Islamic Index (JII); and Indeks Saham Syariah Indonesia (ISSI)
\end{abstract}




\section{PENDAHULUAN}

Selama tahun 2014 iklim investasi di Indonesia berlangsung secara kondusif sebagai akibat dari kebijakan makro ekonomi yang cenderung stabil (tidak ada kebijakan yang diambil oleh pemerintah Indonesia secara ekstrim). Rata-rata IHSG dari tahun 2013 adalah sebesar Rp. 4.400,10 dan pada tahun 2014 rata-rata IHSG sebesar Rp. 5.226,94 atau mengalami kenaikan sebesar 22,29\% (sumber: www.antaranews.com). Bahkan pada bulan April 2015, IHSG mencapai level tertinggi sebesar Rp 5.523,29 sebelum akhirnya ditutup pada posisi Rp. 5.086,43 pada bulan akhir bulan yang sama, April 2015. Di bulan Juli 2015 merupakan nilai IHSG terendah yang berada pada level Rp. 4.771,28 sejalan dengan kejatuhan harian terbesar bursa saham China (sumber: www.sindonews.com). Selain fakta diatas, para analis memperkirakan bahwa kondisi perkembangan perekonomian Indonesia pada tahun 2016 akan meningkat. Hal itu diduga karena para investor merespon secara positif rangkaian kebijakan yang diambil oleh pemerintah.

Selanjutnya, investasi merupakan aktivitas yang dilakukan oleh investor dalam menanamkan dananya pada berbagai jenis pilihan investasi di pasar modal, pada dasarnya investasi mengandung unsur return dan diimbangi dengan adanya risiko. Kesalahan dalam memilih berarti akan kehilangan kesempatan untuk meraih keuntungan. Tetapi hal tersebut dapat ditanggulangi dengan melakukan diversifikasi investasi, yaitu membagi dana pada beberapa jenis investasi sehingga akan mengurangi risiko yang di tanggung, hal inijuga merupakan konsep dasar dari teori portofolio. Permasalahan yang timbul kemudian adalah banyaknya kombinasi portofolio yang dapat dibentuk dari aktiva berisiko yang tersedia di pasar modal.

Dalam membentuk suatu portofolio, akan timbul suatu masalah. Permasalahannya adalah terdapat banyak sekali kemungkinan portofolio yang dapat dibentuk dari kombinasi aktiva berisiko yang tersedia di pasar. Kombinasi ini dapat mencapai jumlah yang tidak terbatas. Terlebihlagi kombinasi ini juga memasukkan aktiva bebas risiko di dalam pembentukan portofolio yang jumlahnya tidak terbatas, maka akan timbul pertanyaan portofolio mana yang akan dipilih oleh investor. Jika investor bersikap rasional, maka mereka akan memilih portofolio yang optimal.Portofolio optimal merupakan portofolio yang dipilih seorang investor dari sekian banyak pilihan yang ada pada kumpulan portofolio efisien. Menurut Tandelilin (2001:47) ada tiga konsep dasar yang perlu diketahui sebagai dasar untuk memahami pembentukan portofolio optimal, yaitu :

1. Portofolio efisien dan portofolio optimal,

2. Fungsiutilitas dan kurva indiferen,

3. Asset berisiko dan asset bebas risiko.

EGP (Elton-Gruber-Padberg, 1976) Model, menyediakan sebuah model alternatif untuk memudahkan proses seleksi portofolio optimal. EGP model didasarkan pada kinerja saham melalui pendekatan reward-to-volatility (RVOL) yakni excess return dibagi systematic risk. Dalam hal penentuan portofolio optimal dengan menggunakan model ini, aset diberi urutan berdasarkan peringkat kinerjanya, mulai dari yang tertinggi hingga terendah. Seluruh aset yang RVOL-nya lebih besar dari cut-off point dimasukkan dalam potofolio optimal, sebaliknya RVOL lebih kecil tidak termasuk dalam portofolio optimal.

Pada penelitian ini akan dipilih beberapa indeks pembanding yaitu Sri Kehati sebagai representasi dari sektor usaha ramah lingkungan dan JII (Jakarta Islamic Index) serta ISSI (Indeks Saham Syariah Indonesia) dengan pertimbangan bahwa indeks ini 
dipilih karena memberikan indikator yang positif seiring dengan kondisi perekonomian yang stabil. Penelitian ini selanjutnya akan mengimplementasikan Elton Grueber Padberg Model dalam penentuan portofolio optimal, serta melakukan analisis varians multivariat untuk mengetahui signifikansi dari return dan risiko yang dibentuk.

\section{PertanyaanPenelitian}

1. Berapakah tingkatreturn dan risiko portofolio optimal untuk indeks LQ45; indeks Sri Kehati, JII dan ISSI dengan menggunakan pendekatan Elton-Gruber-Padberg (EGP) Model di Bursa Efek Indonesia?

2. Bagaimanakah analisis varians multivariat dapat diterapkan pada return dan risiko dari portofolio optimal untuk indeks LQ 45, indeks Sri Kehati, JII, dan ISSI yang dibentuk dengan menggunakan pendekatan Elton-Gruber-Padberg (EGP) Model di Bursa Efek Indonesia?

\section{Tujuan dan Kegunaan Penelitian}

\section{Tujuan Penelitian:}

1. Untuk mengetahui tingkatreturn dan risiko pada portofolio optimal untuk indeks LQ 45, indeks Sri Kehati, Jakarta Islamic Index, dan Indeks Saham Syariah Indonesia dengan menggunakan pendekatan Elton-Gruber-Padberg (EGP) Model di Bursa Efek Indonesia.

2. Untuk mengetahui signifikansi perbedaan return dan risikopada portofolio optimal untuk indeks LQ 45, indeks Sri Kehati, Jakarta Islamic Index, dan Indeks Saham Syariah Indonesia dengan menggunakan pendekatan Elton-Gruber-Padberg (EGP) Model di Bursa Efek Indonesia berdasarkan analisis varians multivariat.

\section{Kegunaan Penelitian}

1. Para investor yang akan menanamkan investasinya di pasar modal agar para investor dapat menentukan portofolio saham yang optimal berdasarkan suatu metode yang dapat dipertanggungjawabkan, tidak hanya berdasarkan spekulasi atau intuisi bisnis semata.

2. Emiten dan calon emiten, agar dapat memberikan informasi penting dalam usahanya untuk dapat memberikan tingkat pengembalian yang menarik dibandingkan dengan risiko yang dihadapi oleh perusahaan yang mengeluarkan saham, agar investor dapat memilih saham perusahaan yang bersangkutan.

3. Para manajer investasi yang berkecimpung dalam dunia pasar modal agar dapat membandingkan antara analisis praktis yang biasa dilakukan dengan analisis teoritis yang dilakukan dalam penelitian ini.

4. Kepentingan ilmu pengetahuan, khususnya manajemen kas dan portofolio yang mana dalam penelitian ini dilakukan pendekatan terhadap permasalahan yang terjadi berdasarkan metode ilmiah, sehingga diharapkan dapat memberikan manfaat dalam perkembangan ilmu pengetahuan itu sendiri.

5. Peneliti lain yang berkeinginan untuk melakukan penelitian-penelitian selanjutnya agar dapat menggunakan hasil penelitian ini sebagai referensi.

\section{Teori Portofolio}

\section{KAJIAN PUSTAKA}

Menurut Suad Husnan (2005:49): "portofolio adalah sekumpulan investasi" Francis (1993:28) menyatakan bahwa: "a portfolio is a collection of diversified investments assets" Dengan demikian diartikan bahwa portofolio terbentuk dari kombinasi berbagai aset investasi yang terdiversifikasi. Elton \& Gruber (2003:2) menyatakan "portfolio analysis is concern with finding the most desireable group of 
securities to hold, given the properties of each of the securities" Weston \& Copeland (1992:396) menyatakan bahwa: "a portfolio is defined as combination of assets"

Dalam portofolio kita memilih kombinasi yang optimal dari tingkat pendapatan ataupun tingkat pengembalian yang diharapkan dengan tingkat resiko yang harus ditanggung oleh investro. Dengan pembentukan portofolio, investor berharap untuk mengurangi risiko dengan cara melakukan diversifikasi dalam investasi yang dilakukan. Hal tersebut dinyatakan oleh Weston \& Copeland (1992: 396) sebagai berikut: "portfolio theory deals with the selection of optimals portfolios; that is, portfolio that provide the highest possible return for any specified degree of risk or the lowest possible risk any specified return"

Pembentukan portfolio ditujukan untuk mengurangi risiko dengan menyebar risiko ke beberapa sekuritas yang dipilih. Fisher and jordan (1995:560) menyatakan bahwa: "portfolio or combination of securities as thought of as helping to spread risk over many securities"

\section{Portofolio Efisien}

Menurut Sharpe, Alexander, dan Bailey (1998:108-109) suatu portofolio dikatakan efisien apabila memiliki tingkat resiko yang sama, mampu memberikan tingkat keuntungan yang lebih tinggi, atau mampu menghasilkan tingkat keuntungan yang sama dengan risiko yang lebih rendah. Dengan kata lain, portofolio dikatakan efisien apabila portofolio tersebut memenuhi kaidah efficient frontier, dimana apabila menghadapi alternatif pilihan investasi, seorang investor yang rasional akan memilih saham atau portofolio yang:

1. Memiliki tingkat pendapatan yang lebih tinggi dengan risiko yang sama

2. Memiliki tingkat risiko yang lebih rendah dengan pendapatan yang sama

\section{Return dan Risiko}

Menurut Tandelilin (2001:47) Return merupakan salah satu faktor yang memotivasi investor berinvestasi dan juga merupakan imbalan atas keberanian investor menanggung risiko atas investasi yang dilakukannya. Sedangkan menurut Subardi (1994:298) Return adalah penghasilan yang diterima dari investasi atau membeli surat berharga ditambah setiap perubahan harga pembeliannya. Jadi, Return merupakan penghasilan yang diterima atas investasi ditambah setiap perubahan harganya sebagai salah satu faktor yang memotivasi investor berinvestasi.

Sedangkan, risiko menurut Tendelilin (2001:48) adalah kemungkinan perbedaan antara return aktual yang diterima dengan return yang diharapkan. Semakin besar kemungkinan perbedaannya, semakin besar risiko investasi tersebut. Menurut Suad Husnan (2001:52) risiko merupakan kemungkinan tingkat keuntungan yang diperoleh menyimpang dari tingkat keuntungan yang diharapkan. Jadi, risiko adalah kemungkinan perbedaan atas return aktual/tingkat keuntungan yang didapatkan dengan return/tingkat keuntungan yang diharapkan.

Lebih lanjut, Tandelilin (2001:60) mendefinisikan diversifikasi sebagai pembentukan portofolio sedemikian rupa sehingga risiko portofolio dapat diminimalkan tanpa mengurangi return yang diharapkan. Diversifikasi merupakan upaya untuk mengurangi risiko dengan melakukan penyebaran investasi sehingga risikonya pun juga ikut tersebar. Diversifikasi terwujud dalam pembentukan portofolio(BAPEPAM, Panduan Reksa Dana). Jadi, Diversifikasi adalah pembentukan portofolio dalam rangka mengurangi risiko dengan penyebaran investasi. 


\section{Model Untuk Menyusun Portofolio Optimal}

Teori portofolio modern mengasumsikan bahwa investor secara fanatik mencoba untuk meminimumkan risiko sementara berupaya untuk memperoleh return tertinggi sebisa mungkin. Teori mengatakan bahwa investor akan bertindak secara rasional, selalu membuat keputusan-keputusan yang diarahkan pada upaya memaksimalkan return untuk level risiko yang dapat diterima.

Model lain yang dapat digunakan dalam pembentukan portofolio optimal adalah Model Indeks Tunggal (Single Index Model) dan Elton-Gruber-Padberg (EGP) Model. Model Indeks Tunggal (SIM) merupakan persamaan regresi linier sederhana dengan return saham individu sebagai variabel dependen dan variabel return pasar sebagai variabel independen.

EGP model didasarkan pada kinerja saham melalui pendekatan reward-tovolatility (RVOL) yakni excess return dibagi systematic risk. Dalam hal ini, aset diberi urutan berdasarkan peringkat kinerjanya, mulai dari yang tertinggi hingga terendah. Seluruh aset yang RVOL-nya lebih besar dari cut-off point dimasukkan dalam portofolio optimal, sebaliknya RVOL lebih kecil tidak termasuk dalam portofolio optimal. Menurut Mc. Gowan, Jr and Toung (1992:52) langkah-langkah dalam proses EGP secara teoritis adalah Menghitung kinerja saham individual atau $\mathrm{RVOL}=(\mathrm{R}-\mathrm{Rf}$ )/ $\beta$, Mengklarifikasikan urutan kinerja saham individual berdasarkan peringkat RVOL, Menentukan Cut - off Point, Memilih Cut - Off Point maksimal ( $\mathrm{C}^{*}$ ), Menentukan asset yang masuk portofolio, membandingkan besarnya RVOL individual dengan cut Off Point maksimal.

\section{Kerangka Konsep Penelitian}

Investasi yang dilakukan berupa saham tidak terlepas dari return dan risiko. Menurut Tandelilin (2001:47) dalam berinvestasi, di samping menghitung return yang diharapkan, investor juga harus memperhatikan risiko yang harus ditanggungnya. Oleh karena itu, investor harus pandai-pandai mencari alternatif investasi yang menawarkan tingkat return diharapkan yang paling tinggi dengan tingkat risiko tertentu, atau investasi yang menawarkan return tertentu pada tingkat risiko terendah.

Menurut Jogiyanto (2008:271) dalam membentuk portofolioakan timbul suatu masalah. Permasalahannya adalah terdapat banyak sekali kemungkinan portofolio yang dapat dibentuk dari kombinasi aktiva berisiko yang tersedia di pasar, kombinasi yang dapat mencapai jumlah yang tidak terbatas.

Berikut akan digambarkan melalui gambar kerangka konsep penelitian untuk memperjelas konsep didalam penelitian ini. 


\section{Gambar Kerangka Konseptual}

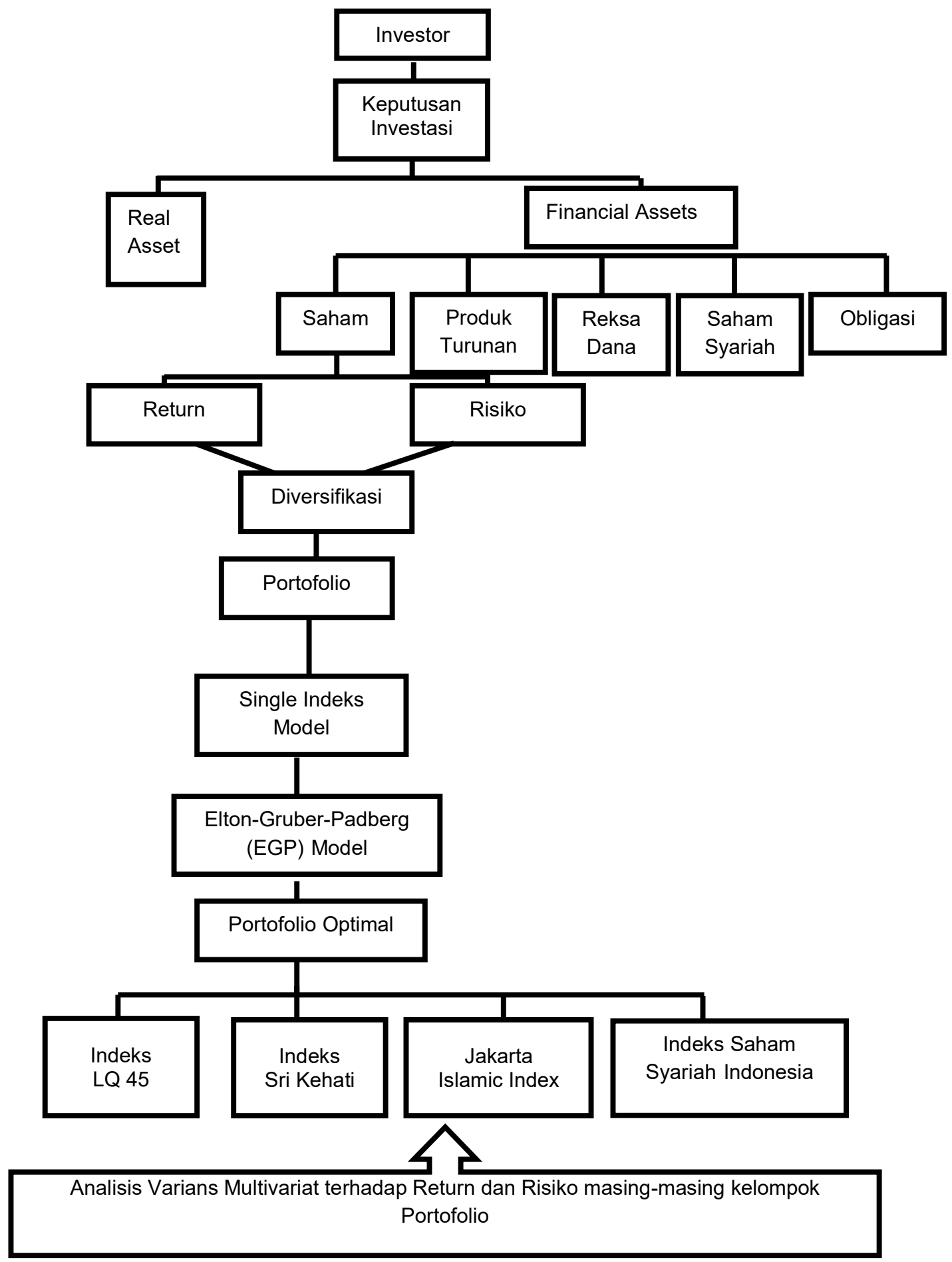

40 | Analisis Varians Multivariat Terhadap Return Dan Risiko Portofolio .... 


\section{METODE PENELITIAN}

\section{Objek Penelitian}

Dalam melakukan penelitian ini yang menjadi objek penelitian adalah semua saham yang tergabung dalam:

1. Indeks LQ 45 di Bursa Efek Indonesia dari tahun 2000-2015 sebanyak 45 saham.

2. Indeks Sri Kehati di Bursa Efek Indonesia dari tahun 2009-2015 sebanyak 25 saham.

3. Jakarta Islamic Indeks dari tahun 2000-2015 sebanyak 30 saham.

4. Indeks Saham Syariah Indonesia dari tahun 2007-2015 berisi seluruh saham yang terkategori syariah yang lolos verifikasi DSN-MUI.

\section{Jenis dan Sumber Data}

\section{Jenis Data}

Jenis data yang digunakan dalam penelitian ini adalah data sekunder, yaitu data yang diperoleh dari literatur yang sudah tersedia, yaitu berupa:Indeks LQ45, indeks Sri Kehati, Jakarta Islamic Index, Indeks Saham Syariah Indonesia dan Suku Bunga Sertifikat Bank Indonesia.

\section{Sumber Data}

Sumber data dalam penelitian ini berasal dari :

1. IndonesianCapital Market Directory yang diterbitkan oleh Economic and Finance Institute.

2. Suku Bunga Sertifikat Bank Indonesia 1 Bulan.

3. Literatur yang berkaitan dengan penelitian ini.

\section{Metode Pengumpulan Data}

Penelitian ini adalah penelitian arsip (archieval research), yaitu penelitian yang menggunakan sumber tertulis dari dokumen perusahaan, text-book, laporan keuangan perusahaan dan pengungkapan yang dilakukan oleh perusahan yang berkaitan dengan data-data keuangan (Smith, 2003). Adapun metode penelitian yang digunakan adalah analisis deskriptif verifikatif. Analisis deskriptif dilakukan dengan cara mengumpulkan saham-saham yang menjadi unit observasi, kemudian mengukur return dan risiko portofolio optimal yang terbentuk dengan menggunakan EGP Model. Setelah, langkah penelitian awal dikerjakan maka langkah yang kedua adalah melakukan proses verifikasi untuk mengetahui apakah terdapat perbedaan yang signifikan untuk return dan risiko portofolio dari masing masing kelompok dengan melakukan uji varians multivariat antara kelompok indeks LQ 45, indeks Sri Kehati, Jakarta Islamic Indeks (JII) dan Indeks Saham Syariah Indonesia (ISSI).

\section{Prosedur Analisis Data}

Dalam penelitian ini menggunakan metode analisis sebagai berikut ini :

1. Deskriptif Kuantitatif, yaitu metode yang digunakan untuk membandingkan data yang ada dari tahun ke tahun dan menghitung perubahan yang terjadi.

2. Deskriptif Kualitatif, yaitu metode yang digunakan untuk menganalisa data yang ada dengan cara membandingkan teori dan konsep dengan permasalahan pokok dalam penelitian ini.

\section{Formulasi yang diterapkan dalam Analisis Data}

Berdasarkan tujuan penelitian yang telah dijelaskan sebelumnya, formulasiatau rumus yang digunakan adalah : 


\section{Penghitungan Return dan Risiko Saham}

$$
\text { Return Saham } \mathrm{R}_{(\mathrm{i})}=\frac{\text { Indeks } \mathrm{t}-\text { Indeks t-1 }}{\text { Indeks } \mathrm{t}-1}
$$

Keterangan :

$\mathrm{R}$ ( i ) = Return masing - masing saham.

Indeks $\mathrm{t} \quad=$ Indeks pada periode $\mathrm{t}$.

Indeks $\mathrm{t}-1=$ Indeks pada periode $\mathrm{t}-1$.

$$
\text { Risiko Saham } \sigma=\sqrt{\frac{\sum(\mathrm{Ri}-\overline{\mathrm{R}})^{2}}{t-1}}
$$

Keterangan :

$$
\begin{aligned}
& \sigma=\text { Standar Deviasi } \\
& \mathrm{Ri}=\text { Return Individual } \\
& \overline{\mathrm{R}}=\text { Tingkat return rata }- \text { rata saham } \mathrm{i} \\
& \mathrm{t} \quad=\text { Jumlah pengamatan }
\end{aligned}
$$

\section{Elton-Gruber-Padberg (EGP) Model}

Pada penelitian ini,EGP Model digunakan untuk menentukan proporsi alokasi dana untuk menghasilkan portofolio optimal. Adapun langkah-langkahnya adalah sebagai berikut :

1. Menghitung Return Individual

Keterangan :

$$
R_{(i)}=\frac{\text { Indeks }_{\mathrm{t}}-\text { Indeks }_{\mathrm{t}-1}}{\text { Indeks }_{\mathrm{t}-1}}
$$

$\mathrm{R}_{(\mathrm{i})} \quad=$ Return masing - masing saham.

Indeks $\mathrm{t}_{\mathrm{t}} \quad=$ Indeks pada periode $\mathrm{t}$

Indekst-1 = Indeks pada periode $\mathrm{t}-1$

2. Menghitung Return Market

$$
R_{(m)}=\frac{\text { Indeks Lq-45 }- \text { Indeks lq- } 45_{\mathrm{t}-1}}{\text { Indeks Lq- } 45_{\mathrm{t}-1}}
$$

Keterangan :

$$
\mathrm{R}_{(\mathrm{m}) \quad=\text { Return Pasar }}
$$

Indeks Lq-45 $=$ Indeks Lq-45 pada periode ${ }_{\mathrm{t}}$ Indeks Lq-45 $\mathrm{t}-1=$ Indeks Lq-45 pada periode $\mathrm{t}$

3. Menghitung Beta

$$
\beta_{i}=\frac{\sum_{t-1}^{n}\left(R_{i}-\overline{R_{i}}\right)\left(R_{m}-\overline{R_{m}}\right)}{\sum_{t-1}^{n}\left(R_{m}-\overline{R_{m}}\right)^{2}}
$$

Keterangan :

$\beta_{\mathrm{i}} \quad=$ Beta

$\mathrm{R}_{\mathrm{i}} \quad=$ Return individual

$\overline{R_{i}} \quad=$ Rata-rata return individual

$\mathrm{R}_{\mathrm{m}} \quad=$ Return market 
$\overline{R_{m}} \quad=$ Rata - rata return market

4. Menghitung Reward to Volatility ( RVOL )

$$
R V O L=\frac{R i-R f}{\beta}
$$

Keterangan :

RVOL = Reward to Volatility .

$\mathrm{R}$ ( i ) = Return

$\mathrm{R}(\mathrm{f}) \quad=$ Risk Free $(\mathrm{SBI})$

$\beta$ ( i ) = Beta portofolio

5. Menghitung Cut - Off Point ( C ( i )* )

Cut Off Point merupakan titik potong atau batas untuk menemukan sahamsaham yang bisa dijadikan sebagai portofolio optimal. Untuk menemukan nilai Cut Off Point, maka diperlukan beberapa data, diantaranya adalah :

a. Data Varians

b. Tingkat keuntungan yang diharapkan dari saham ( return )

c. Tingkat keuntungsn bebas risiko

d. Beta saham

e. Data varians market

Perhitungan Cut - Off Point :

$$
c_{(i)} *=\frac{\operatorname{Var}(m) * \sum(R i-R f) * \beta(i) / \operatorname{var} i}{1+\operatorname{var}(m) *\left(\operatorname{Sum}\left[b_{i}\right]^{2} / \operatorname{Var}(i)\right)}
$$

Keterangan :

$\operatorname{Var}(\mathrm{m})=$ variance market

Var ( i ) = variance individual

Ketentuan= Jika RVOL $>\mathrm{Ci}:$ Termasuk dalam portofolio optimal

Jika RVOL $<\mathrm{Ci}$ : Tidak termasuk dalam portofolio optimal

6. Menentukan Proporsi Alokasi Dana

a. Menghitung Return yang diharapkan dari masing-masing asset dalam portofolio optimal.

$$
\left.\mathrm{Z}(\mathrm{i})=\left[\mathrm{b}(\mathrm{i})^{2} / \operatorname{var}(\mathrm{i})\right]^{*}[\mathrm{R}(\mathrm{i})-\mathrm{R}(\mathrm{f}) / \mathrm{b}(\mathrm{i}))-\mathrm{C}_{(\mathrm{i})} *\right]
$$

Dimana :

$Z_{\text {(i) }}=$ Return yang diharapkan dari masing - msaing asset

$\mathrm{R}$ ( f ) $=$ Risk free ( SBI )

$\mathrm{C}_{(\mathrm{i})} *=\mathrm{C}$ utt off point

b. Menentukan Persentase proporsi dana untuk diinvestasikan

$$
W_{(i)}=\frac{Z(i)}{(\operatorname{sum}(Z i)} \times 100 \%
$$

Keterangan :

$\mathrm{W}(\mathrm{i}) \quad=$ Proporsi dana

Z ( i ) = Return yang diharapkan.

\section{Pengujian Hipotesis}

Adapun pengujian hipotesis dilakukan untuk menjawab pertanyaan-pertanyaan penelitian sebagai berikut : 
"Apakah return dan risiko portofolio optimal dari indeks LQ 45, Sri Kehati, JII dan ISSI yang dibentuk dengan EGP model benar-benar berbeda dan signifikan dengan melakukan analisis varians multivariat?"

\section{HASIL DAN PEMBAHASAN}

Berdasarkan hasil perhitungan yang telah dilakukan dengan menggunakan Microsoft Excel diperoleh hasil return dan risiko portofolio optimal dengan menggunakan EGP Model pada empat kelompok indeks, yaitu LQ 45; SRI KEHATI; JII dan ISSI sebagai berikut:

Tabel 4.1. Perbandingan Return Dan Risiko Portofolio Optimal EGP Model pada Saham LQ 45, SRI KEHATI, JII dan ISSI

\begin{tabular}{|c|c|c|c|c|c|c|c|c|}
\hline TAHUN & $\begin{array}{l}\text { RETUR } \\
\text { N LQ } 45\end{array}$ & $\begin{array}{c}\text { RISIKO } \\
\text { LQ 45 }\end{array}$ & $\begin{array}{c}\text { RETURN } \\
\text { SRI } \\
\text { KEHATI } \\
\end{array}$ & $\begin{array}{c}\text { RISIKO } \\
\text { SRI } \\
\text { KEHATI } \\
\end{array}$ & $\begin{array}{l}\text { RETU } \\
\text { RN } \\
\text { JII }\end{array}$ & $\begin{array}{c}\text { RISIKO } \\
\text { JII }\end{array}$ & $\begin{array}{c}\text { RETU } \\
\text { RN } \\
\text { ISSI }\end{array}$ & $\begin{array}{c}\text { RISIKO } \\
\text { ISSI }\end{array}$ \\
\hline 2000 SMT 1 & 0.2143 & 0.0588 & 0 & 0 & 0.2081 & 0.1712 & 0 & 0 \\
\hline 2001 SMT 1 & 0.4234 & 0.6909 & 0 & 0 & 0.1115 & 0.3698 & 0 & 0 \\
\hline 2001 SMT 2 & 7.5540 & 4.9320 & 0 & 0 & 0.3466 & 0.1552 & 0 & 0 \\
\hline 2002 SMT 1 & 0.9921 & 0.1168 & 0 & 0 & 0.6519 & 0.1031 & 0 & 0 \\
\hline 2002 SMT 2 & 5.9386 & 3.3677 & 0 & 0 & 0.2108 & 0.3183 & 0 & 0 \\
\hline 2003 SMT 1 & 0.9661 & 0.1645 & 0 & 0 & 0.5308 & 0.1306 & 0 & 0 \\
\hline 2003 SMT 2 & 0.2535 & 0.1006 & 0 & 0 & 0.8308 & 0.2109 & 0 & 0 \\
\hline 2004 SMT 1 & 6.5909 & 3.9072 & 0 & 0 & 0.6138 & 0.1718 & 0 & 0 \\
\hline 2004 SMT 2 & 0.6454 & 0.0600 & 0 & 0 & 0.5970 & 0.7735 & 0 & 0 \\
\hline 2005 SMT 1 & 0.3309 & 0.0813 & 0 & 0 & 0.3960 & 0.1059 & 0 & 0 \\
\hline 2005 SMT 2 & 2.9863 & 2.1657 & 0 & 0 & 0.3121 & 0.1211 & 0 & 0 \\
\hline 2006 SMT 1 & 3.0762 & 2.2901 & 0 & 0 & 0.3643 & 0.1127 & 0 & 0 \\
\hline 2006 SMT 2 & 0.4092 & 0.0364 & 0 & 0 & 0.5217 & 0.0456 & 0 & 0 \\
\hline 2007 SMT 1 & 4.1251 & 2.4491 & 0 & 0 & 0.3973 & 0.1085 & 0 & 0 \\
\hline 2007 SMT 2 & 1.6055 & 0.7206 & 0 & 0 & 0.9576 & 0.1684 & 2.1880 & 1.3501 \\
\hline 2008 SMT 1 & 4.4938 & 2.9466 & 0 & 0 & 1.0075 & 0.3916 & 6.5497 & 4.9866 \\
\hline 2008 SMT 2 & 2.2503 & 1.2527 & 0 & 0 & 2.3287 & 1.0128 & 1.7208 & 1.0829 \\
\hline 2009 SMT 1 & 1.2997 & 0.7511 & 0.1085 & 0.0702 & 0.7197 & 0.2913 & 1.1112 & 0.3406 \\
\hline 2009 SMT 2 & 0.9396 & 0.8511 & 0.0381 & 0.0193 & 0.5452 & 0.0832 & 2.4789 & 1.2589 \\
\hline 2010 SMT 1 & 2.1997 & 1.8224 & -0.0460 & -0.0494 & 1.3037 & 1.3227 & 0.0097 & 0.1023 \\
\hline 2010 SMT 2 & 0.3319 & 0.0913 & 0.0772 & 0.0122 & 0.3017 & 0.0976 & -0.0296 & 0.1960 \\
\hline 2011 SMT 1 & 0.2373 & 0.0952 & -0.0525 & -0.0210 & 0.1227 & 0.0855 & -0.1284 & 0.0795 \\
\hline 2011 SMT 2 & 0.3023 & 0.0431 & -0.0054 & -0.0024 & 0.4888 & 0.4676 & 0.0265 & 0.6495 \\
\hline 2012 SMT 1 & 0.1286 & 0.1209 & 0.0103 & -0.0046 & 0.1398 & 0.0490 & 0.1034 & 0.4935 \\
\hline 2012 SMT 2 & 0.3042 & 0.0431 & 0.0007 & -0.02168 & 0.1290 & 0.2381 & 0.1333 & 0.7708 \\
\hline 2013 SMT 1 & 0.6455 & 0.6041 & -0.9459 & 2.6387 & 0.0038 & 0.0660 & 0.7932 & 0.4635 \\
\hline 2013 SMT 2 & 0.0741 & -0.0026 & -0.0626 & -0.0594 & -0.0565 & -0.0024 & -0.1177 & 0.0012 \\
\hline 2014 SMT 1 & 0.0451 & 0.0005 & 0.0434 & 0.0226 & 0.0432 & 0.0003 & 0.1044 & 0.0005 \\
\hline 2014 SMT 2 & -0.0006 & $-1.3 \mathrm{E}-05$ & 0.0422 & 0.0352 & -0.0290 & -0.0002 & 0.0163 & 0.0005 \\
\hline 2015 SMT 1 & -0.0248 & -0.0008 & -0.0674 & -0.0298 & -0.0230 & -0.0007 & -0.0614 & $5.9 \mathrm{E}-05$ \\
\hline
\end{tabular}


Berdasarkan tabel diatas dapat dilihat bahwa nilai return maupun risiko antara pembentukan portofolio optimal dengan EGP Model menunjukkan hasil yang berbeda untuk masing masing index, pembentukan portofolio dengan menggunakan EGP Model menghasilkan variasi trade off dari nilai returndan risiko antar indeks tersebut. Besarnya risiko portofolio menggambarkan besar risiko yang tertanggung oleh investor atas tingkat imbal hasil tertentu. Kendati demikian penelitian Umanto Eko (2008) mengungkapkan bahwa risiko individual(risiko masing-masing saham) terbukti dapat diperkecil dengan membentuk portofolio atau investasi pada berbagai jenis saham. Berikut adalah analisis statistik deskriptif berkenaan dengan return dan risiko portofolio EGP Model pada empat kelompok indeks:

Tabel 4.2. Hasil Statistik Deskriptif Return dan Risiko Portofolio EGP Model pada Indeks LQ 45; SRI KEHATI, JII, dan ISSI

\begin{tabular}{|c|c|c|c|c|c|c|c|c|c|c|c|c|}
\hline & $\mathbf{N}$ & Range & Min & Max & Me & & $\begin{array}{c}\text { Std. } \\
\text { Deviation }\end{array}$ & Variance & Skew & ness & Kurt & sis \\
\hline & Stat & Stat & Stat & Stat & Stat & $\begin{array}{c}\text { Std. } \\
\text { Error }\end{array}$ & Stat & Stat & Stat & $\begin{array}{c}\text { Std. } \\
\text { Error }\end{array}$ & Stat & $\begin{array}{c}\text { Std. } \\
\text { Error }\end{array}$ \\
\hline RETURN LQ45 & 30 & 7.578 & -.024 & 7.5541 & 1.644 & .385 & 2.108 & 4.447 & 1.598 & .427 & 1.669 & .833 \\
\hline RISIKO LQ45 & 30 & 4.934 & -.002 & 4.9321 & .992 & 248 & 1.360 & 1.851 & 1.486 & .427 & 1.388 & .833 \\
\hline $\begin{array}{l}\text { RETURN } \bar{N} \\
\text { SRIKEHATI }\end{array}$ & 30 & 1.054 & -.946 & .1086 & -.028 & .032 & .176 & .031 & -5.125 & .427 & 27.420 & .833 \\
\hline $\begin{array}{l}\text { RISIKO } \\
\text { SRIKEHATI }\end{array}$ & 30 & 2.698 & -.059 & 2.6387 & .086 & .088 & .482 & .233 & 5.458 & .427 & 29.853 & .833 \\
\hline RETURN JII & 30 & 2.385 & -.056 & 2.3287 & .469 & .088 & .484 & .235 & 2.132 & .427 & 6.591 & .833 \\
\hline RISIKO JII & 30 & 1.325 & -.002 & 1.3227 & .239 & .055 & .303 & .092 & 2.381 & .427 & 5.827 & .833 \\
\hline RETURN ISSI & 30 & 6.678 & -.128 & 6.5498 & .496 & .242 & 1.330 & 1.770 & 3.663 & .427 & 15.211 & .833 \\
\hline RISIKO_ISSI & 30 & 4.986 & .000 & 4.9867 & .392 & .174 & .955 & .913 & 4.141 & .427 & 19.450 & .833 \\
\hline $\begin{array}{l}\text { Valid N } \\
\text { (listwise) }\end{array}$ & 30 & & & & & & & & & & & \\
\hline
\end{tabular}

Berdasarkan tabel diatas dari 30 unit observasi pada return portofolio EGP Model pada saham JII menunjukkan bahwa rata-rata return portofolio EGP Model pada saham LQ 45 adalah yang tertinggi, sebesar 1.644, artinya setiap Rp 1,- yang diinvestasikan dengan tingkat risiko sebesar tertentu akan menghasilkan imbal hasil Rp 1.644,-. Sebagaimana penilaian risiko yang mengacu pada return, maka rata-rata risiko portofolio EGP Model pada saham LQ 45 juga menunjukkan nilai yang paling tinggi, yaitu sebesar 0.992 , artinya setiap imbal hasil tertentu, akan memberi risiko tertinggi 0.992 jika diinvestasikan pada portofolio optimal EGP Model di indeks LQ 45. Sementara itu, ketika mekanisme pembentukan portofolio dengan EGP model ini diterapkan pada 3 indeks lainnya, yang merupakan variasi dari berbagai indeks di Bursa Efek Indonesia, maka, return SRI KEHATI memiliki kecenderungan yang berbeda karena return yang dihasilkan jauh dibawah risiko yang dibawa.

Indeks SRI KEHATI adalah indeks yang dibentuk atas kerjasama PT Bursa Efek Indonesia dengan Yayasan Keanekaragaman Hayati Indonesia (Yayasan KEHATI), hasil kerja sama ini adalah diluncurkannya indeks harga saham yang diberi nama Indeks SRI-KEHATI. SRI adalah kependekan dari Sustainable and Responsible Investment.

Indeks ini dimaksudkan untuk memberikan tambahan pedoman investasi bagi pemodal yaitu dengan membuat suatu benchmark indeks baru yang secara khusus memuat emiten yang memiliki kinerja yang sangat baik dalam mendorong usaha-usaha berkelanjutan, serta memiliki kesadaran terhadap lingkungan hidup, sosial dan tata kelola perusahaan yang baik. Kriteria Pemilihan Saham Indeks SRI-KEHATI Indeks 
SRI-KEHATI terdiri dari 25 saham yang dipilih berdasarkan kriteria sebagai berikut: Seleksi Awal Seleksi awal dilakukan untuk memilih saham yang berpotensi menjadi anggota indeks, yaitu dengan mempertimbangkan kriteria-kriteria sebagai berikut:

1. Total Aset,Total aset yang mempresentasikan ukuran dari Emiten SRI, yakni emiten-emiten yang memiliki total aset di atas Rp1 triliun berdasarkan laporan keuangan auditan tahunan.

2. Price Earning Ration (PER), PER emiten yang termasuk dalam kriteria ini adalah yang memiliki PER positif.

3. Free Float Ratio, Free float atau kepemilikan saham publik harus lebih besar dari 10

4. Fundamental

Dari seleksi awal tersebut diperoleh daftar nama emiten yang berpotensi masuk dalam anggota indek SRI-KEHATI. Selanjutnya untuk memilih 25 saham yang terbaik, dilakukan pemeringkatan lebih lanjut dengan mempertimbangkan aspek fundamental yaitu dengan mempertimbangkan 6 faktor utama sebagai berikut:

1. Environmental

2. Community

3. Corporate Governance

4. Human Rights

5. Business Behaviour

6. Labour Practices \& Decent Work

Dalam menentukan dan memilihan saham-saham yang masuk dalam kriteria fundamental ,Yayasan KEHATI menjalin kerja sama dengan independent data provider yaitu OWW-Consulting.

\section{Analisis Terhadap Portofolio Optimal yang dibentuk dengan Menggunakan EGP Model}

Nilai Reward to Volatility(RVOL) yang digunakan dalam penentuan portofolio EGP didasarkan pada kinerja saham yang diukur dengan excess return dibagi systematic risk. Dalam hal ini, aset diberi urutan berdasarkan peringkat kinerjanya, mulai dari yang tertinggi hingga terendah. Seluruh aset yang RVOL-nya lebih besar dari cut-off point dimasukkan dalam portofolio optimal, sebaliknya RVOL lebih kecil tidak termasuk dalam portofolio optimal. Systematic Risk diukur dengan Beta, adapun beta mencerminkan volatilitasreturnsuatu saham terhadap returnpasar. Systematic riskdari suatu saham adalah ukuran relatif risiko individu terhadap risiko pasar. Dengan demikian berarti masing-masing saham memiliki kepekaan yang berbeda terhadap perubahan pasar. Semakin besar koefisien betasaham berarti semakin peka terhadap perubahan pasar dan disebut sebagai saham yang agresif.

Oleh karena sifat systematic risktidak dapat dihilangkan melalui diversifikasi, maka dalam pembentukan portofolio investor perlu mempertimbangkan nilai RVOL tiap saham kandidat.

\section{Uji Perbandingan Return dan Risiko Antara Portofolio Keempat Indeks Saham Yang Terbentuk}

Sebelumnya telah diuraikan statistik deskriptif ketiga portofolio saham yang telah terbentuk. Melalui gambaran tersebut terlihat bahwa return yang ditawarkan portofolio bentukan kelompok indeks LQ-45 lebih tinggi dibanding SRI KEHATI, JII maupun ISSI, kendati hal ini sejalan dengan tingginya tingkat risiko yang juga ditawarkan, terkecuali SRI KEHATI. Oleh karena itu, diperlukan langkah selanjutnya 
untuk menguji hipotesis yang diajukan pada bab sebelumnya yaitu berkaitan dengan apakah terdapat perbedaan yang signifikan pada return dan risiko dari portofolio EGP Model pada empat kelompok indeks, yaitu LQ 45, SRI KEHATI, JII dan ISSI.

Penjabaran dari hasil pengujian hipotesis penelitian berkaitan dengan signifikansi perbedaan return dan risiko portofolio EGP Model pada empat kelompok indeks yaitu, LQ 45, SRI KEHATI, JII dan ISSI dapat disarikan dari tabel dibawah ini.

Tabel 4.3. Hasil Uji Multivariat Perbandingan Return dan Risiko Empat Kelompok Indeks, yaitu LQ 45, SRI KEHATI, JII dan ISSI periode observasi 2000-smt 2 s/d 2015-smt 1

\begin{tabular}{|c|c|c|c|c|c|c|c|c|c|}
\hline \multicolumn{2}{|c|}{ Effect } & \multirow{2}{*}{\begin{tabular}{r|} 
Value \\
.212
\end{tabular}} & \multirow{2}{*}{$\begin{array}{c}\mathbf{F} \\
15.505^{\mathrm{b}}\end{array}$} & \multirow{2}{*}{\begin{tabular}{|c|}
$\begin{array}{c}\text { Hypot } \\
\text { hesis } \\
\text { df }\end{array}$ \\
2.000
\end{tabular}} & \multirow{2}{*}{$\begin{array}{r}\text { Error df } \\
115.000\end{array}$} & \multirow{2}{*}{$\begin{array}{l}\text { Sig. } \\
.000\end{array}$} & \multirow{2}{*}{$\begin{array}{c}\begin{array}{c}\text { Partial } \\
\text { Eta } \\
\text { Square } \\
\text { d }\end{array} \\
.212\end{array}$} & \multirow{2}{*}{$\begin{array}{r}\begin{array}{c}\text { Noncent. } \\
\text { Parameter }\end{array} \\
31.010\end{array}$} & \multirow{2}{*}{$\begin{array}{r}\begin{array}{c}\text { Observed } \\
\text { Power }^{\mathbf{d}}\end{array} \\
.999\end{array}$} \\
\hline \multirow[t]{4}{*}{ Intercept } & $\begin{array}{l}\text { Pillai's } \\
\text { Trace }\end{array}$ & & & & & & & & \\
\hline & $\begin{array}{l}\text { Wilks' } \\
\text { Lambda }\end{array}$ & .788 & $15.505^{\mathrm{b}}$ & 2.000 & 115.000 & .000 & .212 & 31.010 & .999 \\
\hline & $\begin{array}{l}\text { Hotelling' } \\
\text { s Trace }\end{array}$ & .270 & $15.505^{\mathrm{b}}$ & 2.000 & 115.000 & .000 & .212 & 31.010 & .999 \\
\hline & $\begin{array}{l}\text { Roy's } \\
\text { Largest } \\
\text { Root }\end{array}$ & .270 & $15.505^{\mathrm{b}}$ & 2.000 & 115.000 & .000 & .212 & 31.010 & .999 \\
\hline \multirow[t]{4}{*}{ PORTOFOLIO } & $\begin{array}{l}\text { Pillai's } \\
\text { Trace }\end{array}$ & .227 & 4.944 & 6.000 & 232.000 & .000 & .113 & 29.664 & .992 \\
\hline & $\begin{array}{l}\text { Wilks' } \\
\text { Lambda }\end{array}$ & .778 & $5.138^{\mathrm{b}}$ & 6.000 & 230.000 & .000 & .118 & 30.831 & .994 \\
\hline & $\begin{array}{l}\text { Hotelling' } \\
\text { s Trace }\end{array}$ & .281 & 5.330 & 6.000 & 228.000 & .000 & .123 & 31.980 & .995 \\
\hline & $\begin{array}{l}\text { Roy's } \\
\text { Largest } \\
\text { Root }\end{array}$ & .259 & $10.021^{\mathrm{c}}$ & 3.000 & 116.000 & .000 & .206 & 30.062 & .998 \\
\hline \multicolumn{10}{|c|}{ a. Design: Intercept + PORTOFOLIO } \\
\hline \multicolumn{10}{|c|}{ b. Exact statistic } \\
\hline \multicolumn{10}{|c|}{ c. The statistic is an upper bound on $\mathrm{F}$ that yields a lower bound on the significance level. } \\
\hline \multicolumn{10}{|c|}{ d. Computed using alpha $=.05$} \\
\hline
\end{tabular}

Pada tabel diatas dapat dilihat keempat pengujian menunjukkan hasil yang signifikan, hal ini terlihat dari nilai signifikansi (sig.) keempat pengujian lebih kecil dari 0,05 . Dengan demikian maka pada $\alpha=5 \%$ diputuskan untuk menolak Ho dan menerima Ha, sehingga dapat disimpulkan bahwa terdapat perbedaan antara return dan risiko pada portofolio EGP Model yang diterapkan ke empat kelompok indeks yang ada di Bursa Efek Indonesia. Setelah diketahui bahwa secara multivariate terdapat perbedaan yang signifikan pada return dan risiko empat portofolio indeks, selanjutnya dilakukan pengujian secara univariate untuk melihat apakah terdapat perbedaan return, risiko pada keempat portofolio tersebut.

Sebelumnya hasil pengujian secara multivariate menyimpulkan bahwa terdapat perbedaan yang signifikan secara simultan pada return, dan risiko dari keempat portofolio yang terbentuk. Selanjutnya melalui hasil yang terdapat pada tabel diatas akan diuji lebih lanjut apakah secara terpisah/parsial terhadap return dan risiko menunjukkan perbedaaan diantara keempat portofolio indeks tersebut.

Hasil uji univariate juga menunjukkan bahwa terdapat perbedaan yang signifikan pada return dan risiko diantara keempat kelompok portofolio. Hal ini dapat diinterpretasikan bahwa tingkat return dan risiko diantara kedua kelompok ini 
menunjukkan perbedaan yang signifikan. Lebih lanjut Uji post hoc akan dilakukan untuk secara terperinci melihat hasil perbedaan tersebut.

Oleh karena itu berikut dijabarkan tahapan kedua pengujian hipotesis mengenai ada tidaknya signifikansi perbedaan return dan risiko antara keempat kelompok yaitu LQ 45, SRI KEHATI, JII dan ISSI secara univariate (terpisah)

Tabel 4.4. Hasil Uji Univariate Perbandingan Return dan Risiko Portofolio EGP Model pada Empat Kelompok Indeks, yaitu LQ 45, SRI KEHATI, JII, dan ISSI periode observasi 2000-smt 2 s/d 2015-smt 1

\begin{tabular}{|c|c|c|c|c|c|c|c|c|c|}
\hline \multicolumn{10}{|c|}{ Tests of Between-Subjects Effects } \\
\hline Source & $\begin{array}{l}\text { Dependent } \\
\text { Variable }\end{array}$ & $\begin{array}{l}\text { Type III } \\
\text { Sum of } \\
\text { Squares }\end{array}$ & df & $\begin{array}{l}\text { Mean } \\
\text { Square }\end{array}$ & $\mathrm{F}$ & Sig. & $\begin{array}{c}\text { Partial } \\
\text { Eta } \\
\text { Squared }\end{array}$ & $\begin{array}{l}\text { Noncent. } \\
\text { Parameter }\end{array}$ & $\begin{array}{c}\text { Observed } \\
\text { Power }^{\mathrm{c}}\end{array}$ \\
\hline \multirow[t]{2}{*}{ Corrected Model } & RETURN & $45.181^{\mathrm{a}}$ & 3 & 15.060 & 9.291 & .000 & .194 & 27.873 & .996 \\
\hline & RISIKO & $14.142^{b}$ & 3 & 4.714 & 6.105 & .001 & .136 & 18.316 & .956 \\
\hline \multirow[t]{2}{*}{ Intercept } & RETURN & 49.995 & 1 & 49.995 & 30.844 & .000 & .210 & 30.844 & 1.000 \\
\hline & RISIKO & 21.947 & 1 & 21.947 & 28.423 & .000 & .197 & 28.423 & 1.000 \\
\hline \multirow[t]{2}{*}{ PORTOFOLIO } & RETURN & 45.181 & 3 & 15.060 & 9.291 & .000 & .194 & 27.873 & .996 \\
\hline & RISIKO & 14.142 & 3 & 4.714 & 6.105 & .001 & .136 & 18.316 & .956 \\
\hline \multirow[t]{2}{*}{ Error } & RETURN & 188.026 & 116 & 1.621 & & & & & \\
\hline & RISIKO & 89.568 & 116 & .772 & & & & & \\
\hline \multirow[t]{2}{*}{ Total } & RETURN & 283.202 & 120 & & & & & & \\
\hline & RISIKO & 125.656 & 120 & & & & & & \\
\hline \multirow[t]{2}{*}{ Corrected Total } & RETURN & 233.207 & 119 & & & & & & \\
\hline & RISIKO & 103.710 & 119 & & & & & & \\
\hline \multicolumn{10}{|c|}{ a. R Squared $=.194$ (Adjusted R Squared $=.173$ ) } \\
\hline \multirow{2}{*}{\multicolumn{10}{|c|}{ b. R Squared $=.136($ Adjusted R Squared $=.114)$}} \\
\hline \multicolumn{7}{|c|}{ c. Computed using alpha $=.05$} & & & \\
\hline
\end{tabular}

Sebelumnya hasil pengujian secara multivariate menyimpulkan bahwa terdapat perbedaan yang signifikan secara simultan pada return, dan risiko dari keempat kelompok portofolio yang terbentuk. Selanjutnya melalui hasil yang terdapat pada tabel diatas akan diuji lebih lanjut apakah secara terpisah/parsial return dan risiko terdapat perbedaaan diantara ketiga kelompok portofolio tersebut. Pada tabel tersebut dapat

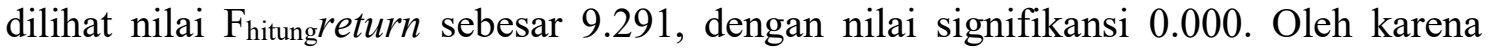
nilai signifikansi menunjukkan nilai kurang dari 0,05 maka pada tingkat kepercayaan 95\% dapat disimpulkan terdapat perbedaan yang signifikan pada return diantara keempat kelompok portofolio yang diuji.

Selanjutnya nilai $F_{\text {hitung }}$ risiko sebesar 6.105 dengan nilai signifikansi sebesar 0.001, karena nilai signifikansi kurang dari 0,05 maka pada tingkat kepercayaan 95\% dapat disimpulkan terdapat perbedaan yang signifikan pada risiko diantara keempat kelompok portofolio.

Hasil uji univariate menunjukkan bahwa terdapat perbedaan yang signifikan pada return dan risiko diantara keempat kelompok portofolio saham bila diuji secara univariate, dan juga secara multivariate. Hal ini dapat diinterpretasikan bahwa tingkat return dan risiko diantara kedua kelompok ini menunjukkan perbedaan yang signifikan. Uji post hoc kemudian akan dilakukan untuk melihat apakah perbedaan yang signifikan tersebut menunjukkan kurang atau lebih antar kelompok tersebut. Hal ini akan sangat menyulitkan pengambilan keputusan apabila dilakukan uji beda yang berulang-ulang.

Oleh karena itu, uji post-hoc sebagai bagian dari Analisis Varians Multivariat dapat memudahkan pengambilan keputusan apabila terdapat tiga atau lebih grup/kelompok. Berikut dipaparkan tahapan pengujian hipotesis dengan uji post hoc 
secara detail mengenai ada tidaknya signifikansi perbedaan return dan risiko antara keempat kelompok yaitu LQ 45, SRI KEHATI, JII dan ISSI

Tabel 4.5. Rangkuman Hasil Uji Post hocReturn dan Risiko Pada Keempat Portofolio, LQ 45, SRI KEHATI, JII dan ISSI

LSD

Multiple Comparisons

\begin{tabular}{|c|c|c|c|c|c|c|c|}
\hline \multirow[b]{2}{*}{$\begin{array}{l}\text { Dependent } \\
\text { Variable }\end{array}$} & \multirow[b]{2}{*}{ (I) PORTOFOLIO } & \multirow[b]{2}{*}{ (J) PORTOFOLIO } & \multirow{2}{*}{$\begin{array}{c}\text { Mean } \\
\text { Difference } \\
(\mathrm{I}-\mathrm{J})\end{array}$} & \multirow[b]{2}{*}{ Std. Error } & \multirow[b]{2}{*}{ Sig. } & \multicolumn{2}{|c|}{$\begin{array}{l}\text { 95\% Confidence } \\
\text { Interval }\end{array}$} \\
\hline & & & & & & \begin{tabular}{l|} 
Lower \\
Bound
\end{tabular} & $\begin{array}{l}\text { Upper } \\
\text { Bound }\end{array}$ \\
\hline \multirow[t]{12}{*}{ RETURN } & \multirow[t]{3}{*}{ LQ 45} & SRI KEHATI & $1.6732^{*}$ & .32872 & .000 & 1.0222 & 2.3243 \\
\hline & & JII & $1.1754^{*}$ & .3287 & .001 & .52434 & 1.8265 \\
\hline & & ISSI & $1.1480^{*}$ & .32872 & .001 & .4969 & 1.7991 \\
\hline & \multirow[t]{3}{*}{ SRI KEHATI } & LQ 45 & $-1.6732^{*}$ & .32872 & .000 & -2.3243 & -1.0222 \\
\hline & & JII & -.4978 & .3287 & .133 & -1.1489 & .1532 \\
\hline & & ISSI & -.5252 & .3287 & .113 & -1.1763 & .1258 \\
\hline & \multirow[t]{3}{*}{ JII } & LQ 45 & $-1.1754^{*}$ & .3287 & .001 & -1.8265 & -.52434 \\
\hline & & SRI KEHATI & .4978 & .3287 & .133 & -.1532 & 1.1489 \\
\hline & & ISSI & -.0274 & .3287 & .934 & -.6784 & .6236 \\
\hline & \multirow[t]{3}{*}{ ISSI } & LQ 45 & $-1.1480^{*}$ & .3287 & .001 & -1.7991 & -.4969 \\
\hline & & SRI KEHATI & .5252 & .3287 & .113 & -.12581 & 1.1763 \\
\hline & & JII & .0274 & .3287 & .934 & -.62367 & .6784 \\
\hline \multirow[t]{12}{*}{ RISIKO } & \multirow[t]{3}{*}{ LQ 45} & SRI KEHATI & $.9050^{*}$ & .22688 & .000 & .4556 & 1.3544 \\
\hline & & JII & $.7530^{*}$ & .2268 & .001 & .3036 & 1.2024 \\
\hline & & ISSI & $.5994^{*}$ & .2268 & .009 & .1501 & 1.0488 \\
\hline & \multirow[t]{3}{*}{ SRI KEHATI } & LQ 45 & $-.9050^{*}$ & .2268 & .000 & -1.3544 & -.4556 \\
\hline & & JII & -.1520 & .2268 & .504 & -.6013 & .2973 \\
\hline & & ISSI & -.3055 & .2268 & .181 & $\begin{array}{l}.7549 \\
\end{array}$ & .14378 \\
\hline & \multirow[t]{3}{*}{ JII } & LQ 45 & $-.7530^{*}$ & .2268 & .001 & -1.2024 & -.3036 \\
\hline & & SRI KEHATI & .1520 & .2268 & .504 & -.2973 & .6013 \\
\hline & & ISSI & -.1535 & .2268 & .500 & -.6029 & .2958 \\
\hline & \multirow[t]{3}{*}{ ISSI } & LQ 45 & $-.5994^{*}$ & .2268 & .009 & -1.0488 & -.15010 \\
\hline & & SRI KEHATI & .3055 & .2268 & .181 & -.14378 & .7549 \\
\hline & & JII & .1535 & .2268 & .500 & -.2958 & .6029 \\
\hline
\end{tabular}

Based on observed means.

The error term is Mean Square(Error) $=.772$.

*. The mean difference is significant at the .05 level.

Pada uji return terlihat perbedaan rata-rata return LQ 45 dengan rata-rata return SRI KEHATI sebesar 1.6732, hasil ini juga menunjukkan meanreturn LQ 45 lebih dari SRI KEHATI dengan nilai signifikansi 0,000, lebih dari 0,05 hal ini menunjukkan perbedaan meanreturn tersebut signifikan di tingkat kepercayaan $95 \%$. Kemudian perbedaan rata-rata return LQ 45 dengan rata-rata return JII sebesar 1.1754 dan hasil pengujian menunjukkan bahwa terdapat signifikansi perbedaan rata-rata return LQ 45 dengan rata-rata return JII (nilai signifikansi 0,001 kurang dari 0,05). Perbedaan ratarata return LQ-45 dengan rata-rata return ISSI sebesar 1.1480 dan hasil pengujian menunjukkan bahwa terdapat perbedaan signifikan antara rata-rata return LQ-45 dengan rata-rata return ISSI (nilai signifikansi 0,001 lebih besar dari 0,05). Sementara itu sebagai rangkuman, dapat disimpulkan berdasarkan tabel diatas bahwa SRI KEHATI dengan JII dan ISSI, tidak menunjukkan signifikansi perbedaan return

Pada uji post hoc untuk risiko terlihat perbedaan rata-rata risiko LQ 45 dengan rata-rata risiko SRI KEHATI sebesar 0.9050, hasil pengujian menunjukkan bahwa terdapat perbedaan yang signifikan antara rata-rata risiko LQ 45 dengan rata-rata risiko SRI KEHATI (nilai signifikansi 0,000 lebih besar dari 0,05). Kemudian perbedaan ratarata risiko LQ 45 dengan rata-rata risiko JII sebesar 0.7530 dan hasil pengujian 
menunjukkan terdapat perbedaan signifikan dengan rata-rata risiko LQ 45 dengan ratarata risiko JII (nilai signifikansi 0,001 kurang dari 0,05 ). Perbedaan rata-rata risiko LQ45 dengan rata-rata risiko ISSI sebesar 0.5994 dan hasil pengujian menunjukkan terdapat signifikansi perbedaan rata-rata risiko LQ-45 dengan rata-rata risiko ISSI (nilai signifikansi 0,009 kurang dari 0,05). Pola yang sama terlihat pula untuk perbandingan risiko antara kelompok LQ 45, SRI KEHATI, JII, dan ISSI dimana ternyata perbedaan risiko diantara kelompok tersebut menunjukkan tidak lolos uji signifikansi 0.05. Hal ini membuktikan bahwa hasil tersebut sesuai dengan konsep teoritis High Risk High Return bahwa pola risiko adalah cerminan dari return yang diberikan.

\section{KESIMPULAN DAN SARAN}

\section{Kesimpulan}

Dari hasil penelitian yang telah diuraikan pada bab sebelumnya, dapat ditarik beberapa kesimpulan sebagai berikut:

1. Portofolio optimal dibentuk oleh EGP Model untuk periode observasi 20002015 pada empat kelompok indeks, yaitu LQ 45, SRI KEHATI, JII dan ISSI menghasilkan kombinasi saham pembentuk portofolio terbanyak 181 saham pada kelompok ISSI di semester dua 2013 dan terendah yaitu terpilihnya 1 saham SRI KEHATI di semester satu 2013. Hal ini menunjukkan semakin banyak jumlah saham memperluas peluang terpilih didalam pembentukan portofolio kendati hasil yang diberi tidak maksimal.

2. Berdasarkan hasil statistik deskriptif dapat diihat bahwa nilai maksimum return dan risiko portofolio, adalah nilai return dan risiko portofolio yang dibentuk dari indeks LQ 45, begitu pula dengan rata-rata dari return, maka risiko portofolio yang paling tinggi adalah rata-rata return dan risiko portofolio yang dibentuk pada LQ 45

3. Hasil pengujian analisis varians multivariat menunjukkan bahwa terdapat perbedaan signifikan antara tingkat returnportofolio optimal EGP Model yang dibentuk pada keempat indeks. Hal ini dapat dibuktikan dengan nilai significance sebesar 0,000. Risiko portofolio optimal EGP Model saham-saham yang dibentuk dari keempat indeks jugamenunjukkan perbedaan yang signifikan.

4. Hasil pengujian univariate juga menunjukkan bahwa terdapat perbedaan antara tingkat return dan risiko portofolio optimal EGP Model pada saham-saham yang tergabung dalam empat indeks, LQ 45, SRI KEHATI, JI, dan ISSI. Uji Post Hoc secara rinci menunjukkan perbedaan kurang dan lebih diantara mean empat kelompok indeks yang diuji, dan hasilnya menunjukkan superioritas LQ 45. Sementara uji post hoc lebih rinci memuat hasil bahwa SRI KEHATI, JII, dan ISSI tidak menunjukkan perbedaan signifikan. Hal ini menyimpulkan bahwa fondasi bisnis antara ketiga kelompok indeks tersebut tidak menujukkan perbedaan berarti.

\section{Saran}

Setelah melakukan analisis dan pembahasan terhadap masalah yang terjadi, yaitu analisis varians multivariat return dan risiko portofolio optimal EGP Model pada empat kelompok indeks (LQ 45, SRI KEHATI, JII, dan ISSI) tahun 2000-2015, maka saransaran yang dapat diberikan adalah:

1. Bagi calon investor, penggunaan EGP Model sangat memudahkan pemilihan investasi. Untuk kurun waktu yang akan datang, seorang investor dapat berinvestasi dengan membentuk portofolio optimal dengan menggunakan 
metode EGP Model dengan kombinasi multi index untuk ketepatan prediksi return dan risiko.

2. Bagi perusahaan yang sahamnya belum memenuhi syarat untuk melakukan perbaikan kinerja perusahaan pada indikator kunci, yaitu Price Earning Ratio, yang menjadi kunci seleksi dari pemilihan indeks. Hal ini akan meningkatkan daya pilih dari emiten tersebut, karena terpilih di berbagai indeks.

3. Bagi penelitian selanjutnya sebaiknya menggunakan Multi Index sehingga memberikan hasil yang memiliki presisi lebih baik. Hal tersebut dikarenakan integrasi dari pasar modal itu. Hal ini sejalan dengan penelitian Elton, Gruber dan Busse (2004) yang menegaskan pentingnya fungsi indeks S\&P 500.

4. Sebaiknya diulas pula secara mendalam tentang perbedaan mekanisme pasar modal di berbagai tempat, selain Indonesia, sehingga penelitian lanjutan dapat memberi hasil yang lebih menyeluruh/komprehensif. 


\section{DAFTAR PUSTAKA}

Ahmad, Kamarrudin, 2003, Dasar - Dasar Manajemen Investasi dan Portofolio, Edisi Revisi kedua, Jakarta.

Alwi, Iskandar Z, 2003, Pasar Modal Teori \& Aplikasi, Yayasan Pancur Siwah, Jakarta.

Anonym, 2001, Investasi di Pasar Modal, Panduan Pemula Seri I, PT. Bursa Efek Jakarta.

Elton, John, M.J Gruber and Padberg.W (1976) "Simple Criteria For Optimal Portfolio Selection “, The Journal of Finance, Vol.31, No.5.

Harianto, Farid dan S, Siswanto, 1998, Perangkat dan Tekhnik Analisis Investasi di Pasar Modal Indonesia, Edisi Pertama, PT. BEJ Jakarta.

Hartono, Jogiyanto, 2007, Teori Portofolio dan Analisis Investasi, BPFE, Yogyakarta.

Husnan, Suad, 1994, Dasar - Dasar Teori Portofolio dan Analisa Sekuritas, Edisi Kedua, Gajah Mada University Press, Yogyakarta.

Koetin, E. A, 1994. Suatu Pedoman Investasi Dalam Efek Indonesia.

Mc.Gowan B Jr dan Yong, 1992, Journal of Managerial Finance, volume 18 number 2 .

Rahmawati, Catur, 2003, Analisis Portofolio Optimal Pada Saham Aktif di Bursa Efek Jakarta, Fakultas Ekonomi-Universitas Jambi

Riyanto, Bambang, 1997, Dasar - Dasar Pembelanjaan Perusahaan, Yogyakarta.

Sartono, Agus, 1995,Manajemen Keuangan, BPFE, Yogyakarta.

Santoso D, Indra, 1996, Kiat Investasi di Pasar Modal, Mega Point, Jakarta.

Sarwidji Widiatmojo, 1996, Cara Sehat Investasi di Pasar Modal, PT. Jurnal Indo Aksara Grapika. Jakarta.

Sunariyah, 2000, Pengantar Pengetahuan Pasar Modal, UPT ANP YKPN, Yogyakarta.

------------, 2004, Pengantar Pengetahuan Pasar Modal. Jakarta

Tandelilin, Eduardus, 2001, Analisis Investasi dan Manajemen Portofolio, Edisi Pertama, BPFE, Yogyakarta.

Yulianti, Handaru Sri dkk, 1996. Manajemen Portofolio dan Analisis Investasi, Cetakan Pertama, Andi Yogyakarta.

Zulkifli, Srinoviarti, 2008, Analisis Penentuan Portofolio Optimal Pada Industri Makanan dan Minuman di Bursa Efek Jakarta Periode 2003-2005 dengan menggunakan Pendekatan EGP Model, Fakultas Ekonomi-Universitas Jambi 